\title{
Proposition of a Catalog to show the Seismic Responses of the Main Presalt Reservoirs Unconformities of the Santos Basin
}

\author{
Thiago Rebeque Carvalho dos Santos ${ }^{1, *}$, Fernando Vizeu ${ }^{1}$, Antonio Fernando Menezes Freire, Luiz Antonio
} Pierantoni Gamboa, Wagner Moreira Lupinacci ${ }^{1}$

${ }^{1}$ GIECAR-UFF

Copyright 2021, SBGf - Sociedade Brasileira de Geofísica.

This paper was prepared for presentation during the $17^{\text {th }}$ International Congress of the Brazilian Geophysical Society held in Rio de Janeiro, Brazil, $16-19$ August 2021.

Contents of this paper were reviewed by the Technical Committee of the $17^{\text {th }}$ International Congress of the Brazilian Geophysical Society and do not necessarily represent any position of the SBGf, its officers or members. Electronic reproduction or storage of any part of this paper for commercial purposes without the written consent of the Brazilian Geophysical Society is prohibited.

\section{Abstract}

The importance of the presalt carbonate reservoirs, since they comprise about $68 \%$ of the Brazilian oil production, led us to propose a specific workflow for seismic interpretation and reservoir characterization. Mapping the sequence limits in the presalt is a complex and challenging task, caused by some factors that make the imaging complex, such as depth of reflectors, structural complexity, thickness of the salt layer above and the heterogeneity of carbonates. In addition, the presence of magmatic intrusions directly impacts the seismic signal. The knowledge about these reservoirs is constantly evolving, and the absence of identical analogues hinders interpretation using conventional techniques. It is important to know if a mapped horizon is either a positive peak, negative peak or if they alternate and, for this, the geological background and information from wells are primordial. To a better understanding about the transition of the Itapema Fm. to the Barra Velha Fm. (Pre-Alagoas Unconformity) and from this formation to the Ariri Fm. (Base of Salt), we created a seismic amplitude catalog to assist in the interpretation. From ten wells of a presalt field of the Santos Basin, we modeled the seismic trace using the convolutional model. This catalog includes the Pre-Alagoas and the Base of Salt unconformities. In addition to the stratigraphic and depositional complexities, there is also the limit of the seismic resolution. The catalog covers two wavelet peak frequencies that are common for the presalt interval, in order to highlight the necessary caution for interpreting and to guide the interpreter through different scenarios. The Itapema Fm. is composed of siliciclastic rocks interspersed with carbonates (mainly coquinas and grainstones with good porosity in the structural highs). Thus, it is expected that the acoustic impedance of this formation is lower than what is observed near the base of the Barra Velha Fm., which is characterized by shrubs, spherulites and laminated carbonates. This transition was characterized by a negative amplitude peak in some wells and in others as a zero cross. In the case of igneous rocks near the top of the Itapema Fm., the higher acoustic impedance of this type of rock turns the amplitude positive. The Base of Salt can be formed by halite or anhydrite and this reflector can marks a passage from carbonates to halite or to anhydrite with varying thickness, which results in different amplitudes, due to the different acoustic impedances, turning this reflector positive or negative, depending on the case. On the other hand, in some wells, there are igneous intrusions at the top of the Barra Velha Fm., which also modifies the signal of the Base of Salt. When interpreting the base of the salt, with a model in mind considering the transition of carbonates to halite, a high positive seismic peak response is expected. However, this response was ambiguous in cases below the tuning thickness of anhydrite and in the presence of igneous intrusive bodies.

Keywords: carbonate reservoirs, seismic catalog, presalt unconformities. 